\title{
Pengaruh Debt Financing Dan Equity SERAMBI Financing Terhadap Profit Expense Ratio Pada Bank Syariah M andiri Tahun 2010-2019
}

\author{
Deky A nwar*, Riski Ananda A melia \\ Fakultas Ekonomi dan Bisnis Islam, UIN Raden Fatah \\ Pal embang
}

\begin{abstract}
Purpose This study aims to determine the effect of the level of financing with the principle of debt financing and equity financing to profit expense ratio in Bank Syariah Mandiri in 2010-2019. Methods- The sample selection technique uses purposive sampling. In this study the authors used the method of multiple linear regression analysis. The data analysis technique used is the classic assumption test and multiple linear analysis. Findings- Based on the results of the analysis shows that financing with the principle of debt financing does not affect the profit expense ratio, while financing with the principle of equity financing affects the profit expense ratio.
\end{abstract}

\begin{abstract}
Abstrak
Tujuan- Penelitian ini bertujuan untuk mengetahui pengaruh tingkat pembiayaan dengan prinsip debt financing dan equity financing terhadap profit expense ratio pada Bank Syariah Mandiri tahun 2010-2019. M etode- Teknik pemilihan sampel menggunakan purposive sampling. Dalam penelitian ini penulis menggunakan metode analisis regresi linier berganda. Teknik analisis data yang digunakan adalah uji asumsi klasik dan analisis linear berganda. Hasil- Berdasarkan hasil analisis menunjukkan bahwa pembiayaan dengan prinsip debt financing tidak berpengaruh terhadap profit expense ratio, sedangkan pembiayaan dengan prinsip equity financing berpengaruh terhadap profit expense ratio.
\end{abstract}

Pedoman Sitasi: Anwar, D., \& Amelia, R. (2020). Pengaruh Debt Financing Dan Equity Financing Terhadap Profit Expense Ratio Pada Bank Syariah Mandiri Tahun 2010-2019. SERAM BI: Jurnal Ekonomi M anajemen Dan Bisnis Islam, 2(2), 103 - 112

DOI: https:/ / doi.org/ 10.36407/ serambi.v2i2.186
Received 06 Mei 2020

Revised 12 Jun 2020

A ccepted 15Jun 2020

Online first 19Jun 2020

\section{Paper type}

Research paper

$\triangle$ Email Korespondensi*: dekyanwar_uin@radenfatah.ac .id

Keywords: debt financing, equity financing, profit expense ratio

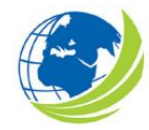

SERAMBI: Jurnal Ekonomi dan Bisnis Islam, Vol 2, N o.2, 2020,

pp. $103-112$

elSSN 2685-9904 


\section{Pendahuluan}

Saat ini, operasi bisnis bank syariah menjadi lebih menantang baik pasar global maupun domestik. Kondisi ini mendorong bank syariah untuk meningkatkan kinerja bisnis mereka agar tetap kompetitif dan menguntungkan baik domestik maupun internasional di keuangan. Namun, profitabilitas; yang merupakan indikator umum kinerja bank, dipengaruhi oleh berbagai faktor. Faktor-faktor yang akan mempengaruhi komersial profitabilitas bank dapat diklasifikasikan ke dalam dua kategori utama, penentu internal dan eksternal. Penentu internal mengacu pada faktor-faktor yang dapat dikendalikan oleh manajemen sedangkan faktor eksternal adalah variabel-variabel yang di luar kendali manajemen (Murzinova et al., 2018; Quan et al., 2019).

Baik bank syariah dan konvensional dikenal sebagai institusi yang sama-sama menguntungkan (Zarrouk, Jedidia, \& Moualhi, 2016). Evaluasi profitabilitas merupakan masalah penting bagi investor untuk keputusan investasi. Meningkatkan kinerja dan stabilitas bank dapat menajdi sinyal kepada deposan untuk menjaga atau menarik dana mereka. Meski demikian, ada perbedasan fundamental antara bank syariah dan konvensional dari sisi struktur dan aktivitas pendanaan. Pertama, aktivitas bank syariah harus sesuai dengan syariah. Perbedaan utama antara bank syariah dan konvensional adalah larangan suku bunga. Selanjutnya, transaksi harus bebas dari gharar dan segala bentuk spekulasi. Semua transaksi keuangan harus didukung oleh aset nyata. Bank syariah tidak mengizinkan investasi di perusahaan mana pun yang aktivitasnya dilarang oleh Al-Quran, seperti produk daging babi dan alkohol. Kedua, ada kekhasan perbankan syariah yang berkaitan dengan solvabilitas. Ketiga, bank syariah lebih muda dan menikmati lebih sedikit pengalaman dibandingkan dengan yang konvensional (Zarrouk et al., 2016).

Salah satu studi yang dilakukan oleh Olson dan Zoubi (2008) mempelajari dan membandingkan bank syariah dan konvensional dalam GCC selama periode 2000 - 2005. Menggunakan 26 rasio keuangan, mereka menemukan bahwa profitabilitas antara syariah dan konvensional tidak jauh berbeda. Namun, bank syariah ternyata kurang efisien dan beroperasi dengan risiko lebih tinggi. Alasan bank syariah berisiko karena bank syariah memegang dana yang akan digunakan jika terjadi kredit macet. Bank konvensional di sisi lain menawarkan dana simpanan yang sepenuhnya ditentukan oleh suku bunga sedangkan Bank Islam menawarkan dana simpanan yang mirip dengan ekuitas karena mereka berbagi jenis risiko terbalik (I brahim \& Mahmuda, 2018). Kondisi tersebut menunjukkan bahwa masih terjadi kendala internal perbankan syariah seperti pemahaman akan esensi perbankan syariah yang masih kurang, adanya orientasi bisnis dan usaha yang lebih diutamakan, kualitas serta kuantitas sumber daya yang belum memadai, sikap aversion to effort serta aversion to risk. Sedangkan kendala eksternalnya dikarenakan karakter pembiayaan dengan prinsip equity financing yang memerlukan tingkat kejujuran yang sangat tinggi dari pihak yang mendapatkan pembiayaan.

Penelitian sebelumnya telah banyak mengidentifikasi faktor yang dapat mempengaruhi profitabilitas perbankan syariah (Mariam, Isnurhadi, \& Taufik, 2016; Firdaus \& Prasetyo, 2017; Quan et al., 2019), dan memberikan kesimpulan yang berbeda. Mariam et al, (2016) dab Firdaus dan Prasetyo (2017) menemukan bahwa pembiayaan utang dan pembiayaan ekuitas memiliki pengaruh signifikan terhadap rasio beban laba bank syariah. Sementara penelitian Quan et al. (2019) ukuran bank, likuiditas, risiko kredit, manajemen pengeluaran, dan produk domestik bruto ditemukan tidak signifikan mempengaruhi kinerja bank syariah. Studi lain yang dilakukan Pakpahan (2013) menyatakan bahwa D ebt Financing tidak berpengaruh terhadap Profit Expense Ratio (PER). Dari berbagai perbedaan tersebut terlihat bahwa determinan profitabilitas 
perbankan syariah telah memberikan kesimpulan yang berbeda, baik dari sisi signifikansi maupun proxy pengukurannya (beberapa studi menggunakan ROA, ROE dan terakhir adalah PER).

Didasarkan pada gap tersebut penelitian tertarik untuk meneliti bagaimana pengaruh pembiayaan jual beli dan pembiayaan bagi hasil pada salah satu bank syariah di Indonesia yaitu Bank Syariah Mandiri yang sudah berdiri sejak tahun 1999 sampai saat ini. Produk-produk pembiayaan Bank Syariah Mandiri yang banyak macam disediakan untuk para nasabahnya, misalnya pembiayaan yang diberikan untuk modal kerja, investasi atau keperluan konsumsi. Manfaat studi ini dapat dijadikan referensi yang bermanfaat untuk Bank Syariah Mandiri dalam meningkatkan kinerja pada produk-produk yang berpengaruh terhadap pertumbuhan asetnya, sesuai dengan garis besar prinsip perbankan syariah.

\section{Kerangka teoritis}

Commercial Loan Theory

Commercial Loan Theory beranggapan bahwa bank-bank hanya boleh memberikan pinjaman dengan surat dagang jangka pendek yang dapat dicairkan dengan sendirinya (self liquiding). Pada prinsipya teori ini menitikberatkan sisi aktiva dari neraca bank dalam memenuhi kebutuhan likuiditas bank. Likuiditas bank menurut teori ini akan terjamin apabila aktiva produktif bank yang terdiri dari kredit jangka pendek dicairkan dalam kegiatan usaha yang berjalan secara normal. Secara khusus teori menyatakan bahwa bank harus memberikan teori jangka pendek atau self liquiditing loans, seperti kredit yang digunakan untuk modal kerja usaha untuk memproses suatu produksi secara musiman atau yang bersi fat sementara. Peran Commercial Loan Theory dalam landasan penelitian ini adalah bank memberikan pembiayaan kepada masyarakat dengan perjanjian bagi hasil yang telah disepakati (Siamat, 2005).

H ubungan antar variabel

Menurut Muhammad (2005:209) pembiayaan dengan prinsip debt financing merupakan salah satu komponen penyusun aset terbesar di perbankan syariah yang menghasilkan pendapatan berupa margin/ mark up. Dengan diperolehnya mark up tersebut, maka akan mempengaruhi besarnya laba yang diperoleh bank syariah, serta pada akhirnya mampu mempengaruhi peningkatan profitabilitas Bank U mum Syariah.

Mariam, Isnurhadi, dan Taufik, (2016) menemukan bahwa terdapat hubungan langsung atau positif antara Pembiayaan Utang dan Pembiayaan Ekuitas terhadap Rasio Beban Laba. Sementara pengaruh Pembiayaan Utang dan Pembiayaan Ekuitas sebagai variabel independen (X) secara simultan mempengaruhi Rasio Beban Profit sebagai variabel dependen ( $\mathrm{Y}$ ) pada bank syariah, itu berarti bahwa Pembiayaan Utang dan Pembiayaan Ekuitas secara simultan memiliki dampak yang signifikan terhadap Rasio Biaya Keuntungan Syariah bank. Nilai koefisien determinasi (R2) yang diperoleh adalah 0,516 atau 51,6\%. Ini berarti bahwa variasi dari variabelvariabel independen ini, yaitu Pembiayaan Utang dan Pembiayaan Utang, memberikan kontribusi efek pada Rasio Biaya Keuntungan Bank Islam. Sesuai dengan hasil analisis penelitian ini, dapat dilihat bahwa Pembiayaan Ekuitas dominan dalam mempengaruhi Rasio Biaya Keuntungan Bank Islam dibandingkan Pembiayaan Utang. Peneliti menyarankan manajemen bank syariah untuk memprioritaskan sistem Pembiayaan Ekuitas, terutama Musharaka, karena sistem pembiayaan tersebut paling sesuai dengan hukum Islam untuk diterapkan pada umat Islam. Dukungan empirik yang telah dilakukan dalam penelitian sebelumnya (Susilawati, 2016) yang menyatakan bahwa adanya pengaruh positif antara debt financing terhadap profit expense 
ratio.Berdasarkan teoritik dan juga hasil penelitian sebelumya, maka dapat dirumuskan hipotesis sebagai berikut:

$\mathrm{H}_{1}$ : terdapat pengaruh positif antara debt financing terhadap profit expense ratio

Hubungan Equity Financing dengan Profit Expense Ratio

Equity financing merupakan salah satu komponen penyusun aset pada perbankan syariah. Dari pengelolaan equity financing, bank syariah memperoleh pendapatan sesuai dengan nisbah yang disepakati dengan nasabah. Pendapatan yang diperol eh akan mempengaruhi besarnya laba yang akan diperoleh oleh bank (Muhammad, 2005). Hasil penelitian menunjukkan bahwa pembiayaan utang parsial berpengaruh signifikan terhadap laba expenseratio, dan pembiayaan ekuitas juga secara signifikan mempengaruhi rasio biaya laba. Secara bersamaan, pembiayaan utang dan pembiayaan ekuitas secara signifikan mempengaruhi rasio biaya laba perbankan syariah (Firdaus dan Prasetyo, 2017). Studi lain yang dilakukan Pakpahan (2017), Hidayat (2013), dan Sukamto (2010) yang menyatakan bahwa Equity Financing berpengaruh terhadap Profit Expense Ratio. Berdasarkan dasar teoritik dan juga hasil penelitian sebelumya, maka dapat dirumuskan hipotesis sebagai berikut:

$\mathrm{H}_{2}$ : terdapat pengaruh positif antara equity financing terhadapprofit expense ratio

\section{Metodologi}

Desain Penelitian

Penelitian ini adalah penelitian berjenis kuantitatif dengan pendekatan korelasional. Data yang digunakan adalah data berupa laporan keuangan triwulan Bank Syariah Mandiri selama periode 2010-2019. Data keuangan yang digunakan merupakan laporan keuangan yang dipublikasikan. Pada penelitian ini pengumpulan data dengan melakukan studi pustaka. Data diperoleh dari laporan keuangan triwulan Bank Syariah Mandiri yang diakses melalui www.mandirisyariah.co.id.

Dalam penelitian ini data kuantitatif berupa laporan keuangan dan perhitungan rasio keuangan, dan sumber data berupa data sekunder dengan memperoleh laporan keuangan publikasi yang dipublikasikan oleh Bank Syariah Mandiri. Selain itu peneliti juga memperoleh data dari studi literatur/ kepustakaan dengan mempelajari, mengkaji serta menelaah literaturliteratur yang berkaitan dengan masalah yang diteliti berupa buku, jurnal, dan makalah yang berkaitan dengan penelitian.

Objek Penelitian

Objek penelitian ini diambil dari salah satu perbankan syariah yang ada di Indonesia, yaitu PT. Bank Syariah Mandiri. Penentuan objek ini berdasarkan pertimbangan bahwa PT. Bank Syariah Mandiri merupakan bank yang melandaskan kegiatan operasionalnya dengan prinsip syariah. PT. Bank Syariah Mandiri juga dipandang mampu memberikan informasi dan kebutuhan datadata yang akan diteliti terkait pembiayan debt financing dan equity financing, serta profit expense ratio.

Pengukuran V ariabel

Menurut Muflih (2006:276) debt financing merupakan transaksi jual beli antara bank dan nasabah dimana harga, jumlah, dan waktu penyerahan barang sudah ditentukan diawal akad. Pembiayaan jual beli terdiri dari akad murabahah, akad salam dan akad istihna'. Untuk menghitung debt financing dapat dihitung dengan menggunakan rumus: 
$\mathrm{DF}=\frac{\text { Jumlah DebtFinancing }}{\text { Total Pembiayaan }}$

Equity financing merupakan pembiayaan dengan prinsip bagi hasil dimana akad kerjasama antara bank sebagai pemilik modal dengan nasabah sebagai pengelola modal untuk memperoleh keuntungan dan membagi keuntungan yang diperoleh berdasarkan kesepakatan atau nisbah yang disepakati. Equity financing dapat dihitung dengan menggunakan rumus:

$\mathrm{EF}=\frac{\text { Jumlah EquityFinancing }}{\text { Total Pembiayaan }}$

Profit Expense Ratio (PER) adalah rasio yang digunakan dalam menilai kinerja profitabilitas, dimana bila rasio ini menunjukkan nilai yang tinggi mengindikasikan bahwa bank menggunakan biaya secara efisiensi dan menghasilkan profit yang tinggi dengan beban-beban yang ditanggungnya (Ascarya, 2005). Profit expense ratio dapat dihitung dengan menggunakan rumus:

$\mathrm{PER}=\frac{\text { Profit }}{\text { Total Expense }}$

Teknik A nalisis

Metode analisis yang digunakan adalah analisis regresi linier berganda dengan bantuan program SPSS. Analisis regresi linier berganda digunakan untuk mengetahui pengaruh antara variabel independen terhadap dependen dan seberapa besar pengaruh antara variabel bebas terhadap variabel dependen. Analisis linier berganda ini digunakan untuk mengetahui pengaruh debt financing dan equity financing terhadap profit expense ratio pada Bank Syariah Mandiri tahun 2010-2019. Sebelum dilakukan analisis regresi, dilakukan terlebih dahulu uji asumsi klasik.

\section{Hasil dan pembahasan}

A nalisis regresi berganda digunakan untuk mengetahui dan menganalisis variable dapat dilihat pada tabel berikut:

Tabel 1. Hasil Penelitian

\begin{tabular}{|l|l|l|l|l|}
\hline Variabel & Koefisien & Uji t & Sig & VIF \\
\hline Konstanta & $-0,360$ & $-1,919$ & 0,063 & - \\
\hline DF & $-0,204$ & $-1,146$ & 0,259 & 1,781 \\
\hline EF & 1,387 & 3,216 & 0,003 & 1,781 \\
\hline A djustedR ${ }^{2}$ & 0,251 & & \\
\hline
\end{tabular}

Sumber : data diolah (2020)

Nilai konstanta sebesar -0,360 meyatakan bahwa jika variabel debt financing dan equity financing dianggap konstan, maka nilai profit expense ratio adalah sebesar 0,360\%. Debt financing (DF) mempunyai nilai koefisien regresi dengan arah negative sebesar 0,204, artinya jika terjadi peningkatan debt financing maka profit expense ratio akan menurun sebesar 0,204. Equity financing 
(EF) mempunyai nilai koefisen regresi dengan arah positif sebesar 1,387, artinya ika terjadi peningkatan equity financing maka profit expense ratio akan meningkat sebesar 1,387.

\section{Pembahasan}

Seiring dengan tanggapan positif masyarakat pada produk dan layanan bank syariah, perkembangan lembaga-lembaga keuangan syariah di Indonesia cukup signifikan. Sebagai lembaga keuangan yang lebih banyak berorientasi pada kebutuhan usaha kecil, telah bermunculan $\mathrm{Hal}$ tersebut memang tidak bisa dilepaskan dari peranan Lembaga Keuangan mikro Syariah (LKMS) yang menjangkau masyarakat secara luas. Lembaga ini dapat berbentuk Bank Pembiayaan Rakyat Syariah (BPRS), Baitul Mal wat-Tamwil (BMT), dan Koperasi Pondok Pesantren (Kopontren). Luasnya jangkauan lembaga menjadikan institusi ini mempunyai peran yang cukup strategis dalam menjangkau transaksi syariah mikro kecil dan menengah seluruh Indonesia.

Pembiayaan merupakan salah satu produk yang banyak diminati. Produk ini berupa penyaluran dana bank syariah atau pendanaan yang diberikan suatu pihak kepada pihak lain untuk mendukung investasi yang telah direncanakan baik dilakukan sendiri maupun lembaga. Komponen pembiayaan merupakan komoditas utama perbankan syariah dalam memperoleh keuntungan. Dimana keuntungan yang diperoleh perbankan akan menjamin kelangsungan usaha perbankan syariah di masa yang akan datang. Bank syariah menilai bahwa pembiayaan memiliki risiko tinggi dalam hal kerugian yang dapat terjadi dalam kurun waktu pembiayaan tersebut sehingga dapat menyebabkan turunnya laba suatu perusahaan. Pemberian pembiayaan merupakan aktifitas terbesar sekaligus mempunyai resiko terbesar (high risk high return). Penelitian ini menguji pengaruh Debt Financing (DF) dan Equity Financing (EF) terhadap profitabilitas perbankan syariah. Hasil penelitian dapat dijelaskan sebagai berikut:

Hipotesisl. Hasil statistik uji t untuk variabel Debt Financing (DF) diperoleh nilai signifikansi sebesar 0,259>0,05. Oleh karena nilai signifikansi lebih besar dari 0,05 dannilai t test sebesar -1,146; maka dapat disimpulkan bahwa debt financing tidak berpengaruhterhadap profit expense ratiopada laporan keuangan Bank Syariah Mandiri tahun 2010-2019. Hasil dari penelitian ini konsisten dengan penelitian sebelumya yang dilakukan oleh Pakpahan (2013) yang menyatakan bahwa D ebt Financing tidak berpengaruh terhadap Profit Expense Ratio. Jadi, dapat dikatakan bahwa peningkatan pembiayaan secara tidak konsisten sejalan dengan peningkatan terhadap profit expense ratio.

Hipotesis 2. Hasil statistik uji t untuk variabel Equity Financing (EF) diperoleh nilai signifikansi sebesar $0,003<0,05$. Oleh karena nilai signifikansi lebih kecil dari 0,05 dan nilai $t$ test sebesar 3,216; maka dapat disimpulkan bahwa equity financing berpengaruh terhadap profit expense ratiopada laporan keuangan Bank Syariah Mandiri tahun 2010-2019. Hasil dari penelitian ini konsisten dengan penelitian sebelumya yang dilakukan oleh Hidayat (2013), dan Sukamto (2010) yang menyatakan bahwa Equity Financing berpengaruh terhadap Profit Expense Ratio. Hal ini dikarenakan equity financing lebih bersifat produktif dibandingkan pembiayaan dengan sistem debt financing. Dengan demikian dapat dikatakan bahwa meningkatnya equity financing diikuti dengan meningkatnya profit expense ratio.

Hasil uji adjusted R2 pada penelitian ini diperoleh nilai sebesar 0,251 . Hal ini menunjukkan bahwa Profit Expense Ratio dipengaruhi oleh tingkat Debt Financing (DF) dan tingkat Equity Financing (EF) sebesar $25,1 \%$, sedangkan sisanya sebesar $74,9 \%$ dipengaruhi ol eh faktor lain yang tidak diteliti dalam penelitian ini. Beberapa factor lain kemungkinan dapat menjelaskan PER lebih baik dibandingkan debt financing dan equity financing. 
Haron, Shanmugam, dan Doran (1997) secara komprehensif menemukan bahwa faktorfaktor internal seperti likuiditas, total pengeluaran, dana yang diinvestasikan dalam sekuritas syariah, dan persentase rasio bagi hasil antara bank dan peminjam dana sangat berkorelasi dengan tingkat total pendapatan yang diterima oleh bank syariah. Efek serupa ditemukan untuk faktor-faktor eksternal seperti suku bunga, pangsa pasar dan ukuran bank. Penentu lain seperti dana yang disetorkan ke giro, total modal dan cadangan, persentase bagi hasil antara bank dan deposan, dan jumlah uang beredar juga memainkan peran utama dalam mempengaruhi profitabilitas bank syariah. Studi ini juga menemukan bahwa sifat pasar, baik monopolistik atau kompetitif, tidak memiliki keterkaitan dengan profitabilitas bank syariah. Oleh karena itu, kebijakan proteksionisme yang diadopsi ol eh beberapa negara Muslim dianggap sebagai strategi yang tidak tepat untuk pengembangan sistem perbankan Islam di masa depan. Ben Khediri dan Ben-Khedhiri (2009) juga memberikan bukti yang menunjukkan bahwa kapitalisasi dan efisiensi manajemen meningkatkan profitabilitas bank. Hasil juga menunjukkan bahwa profitabilitas bank berhubungan positif dengan, pertumbuhan ekonomi, inflasi dan konsentrasi bank.

\section{Kesimpulan}

Kesimpulan

Penelitian ini ditujukan untuk mengetahui pengaruh debt financing dan equity financing terhadap profit expense ratio pada Bank Syariah Mandiri tahun 2010-2019. Berdasarkan hasil analisis diketahui bahwa debt financing tidak berpengaruh terhadap profit expense ratio sedangkan equity financing berpengaruh terhadap profit expense ratio.

Implikasi Praktis dan keterbatasa

Equity financing lebih bersifat produktif dibandingkan pembiayaan dengan sistem debt financing, walaupun tidak terlalu banyak diminati seperti pembiayaan dengan sistem equity financing. Pembiayaan dengan sistem equity financing lebih selektif dalam penyalurannya karena hanya diberikan kepada nasabah yang sudah memiliki usaha. Kemudian dengan adanya kontrak kesepakatan untung dan rugi yang ditanggung bersama serta nisbah bagi hasil yang telah disepakati di awal akad lebih membuat pembiayaan dengan sistem equity financing lebih jelas karena terpantau usahanya.

Penelitian ini memiliki keterbatasan dari sisi objek penelitian yang hanya mencakup satu bank dengan periode terbatas. Selain itu, variabel yang digunakan hanya dari sisi internal sehingga tidak dapat menjelaskan secara baik profitabilitas bank syariah. Berdasarkan keterbatasan tersebut maka riset mendatang perlu menambil objek studi yang lebih besar, misalnya seluruh Bank Umum Syariah (BUS) dengan periode pengamatan 10 tahun. Penelitian selanjutnya juga disarankan menambahkan variabel independen dari penelitian ini dengan variabel lain yang disinyalir dapat mempengaruhi profit expense ratio. Beberapa faktor internal seperti likuiditas, total pengeluaran, dana yang diinvestasikan dalam sekuritas syariah, dan persentase rasio bagi hasil antara bank (Haron et al., 1997) dan faktor eksternal seperti suku bunga, pangsa pasar dan ukuran bank juga dapat dijadikan predictor yang disarankan untuk riset berikutnya. 


\section{Daftar Pustaka}

Ascarya, D. Y. (2005). Bank Syariah: Gambaran Umum. Jakarta: Pusat Pendidikan dan Studi Kebanksentralan (PPSK) Bank Indonesia.

Ben Khediri, K., \& Ben-Khedhiri, H. (2009). Determinants of Islamic bank profitability in the MEN A region. International Journal of M onetary E conomics and Finance, 2(3-4), 409-426.

Endri. (2008) Analisis Kinerja Keuangan Dengan Menggunakan Rasio-Rasio Keuangan Dan Economic Value Added Study Kasus PT. Bank Syariah Mandiri . Jurnal Y ang Dipublikasikan, Vol. 13, N 0. 1

Firdaus, A. M., \& Prasetyo, A. (2017). Pengaruh Debt Financing dan Equity Financing Terhadap Profit Expense Ratio Perbankan Umum Syariah Periode 2011-2015. Jurnal Ekonomi Syariah Teori dan Terapan, 4(6), 505.

Ibrahim, A. A., \& Mahmuda, M. (2018). Profitability And Liquidity Of Conventional Banks And Islamic Banks In Nigeria: A Comparative Study (2012-2015). Lafia J ournal Of E conomics A nd $M$ anagement Sciences, 3(1), 212-212.

Hanafi, M .M. (2012). Analisis Laporan Keuangan, Edisi Keempat, Yogyakarta: U PP STIM YK PN .

Haron, S., Shanmugam, B., \& Doran, H. (1997). Determinants of Islamic bank profitability. Retrieved from https:/ / rune.une.edu.au/ web/ handle/ 1959.11/ 6691

Hidayat, M. D. (2013). Pengaruh Debt Financing dan Equity Financing Terhadap Profit Expense Ratio Perbankan Syariah. Skipsi S1 Fakultas Ekonomi Dan Bisnis U niversitas Brawijaya, M alang.

Kartikasari, M. (2014) Penilaian Kinerja Keuangan Menggunakan Analisis Rasio pada Bank Mandiri di BEI. Jurnal IImu \& R iset M anajemen, Vol. 3, N 0. 11

Kasmir. (2003) Manajemen Perbankan. Jakarta: Rajawali Pers

Lidia Desiana dan Aryanti. (2017) Manajemen Keuangan Bank Syariah.Palembang: N oerFikri

Malik, T. A. A . (2019). Pengaruh Tingkat Debt Financing, Equity Financing, dan Lease Financing Terhadap Profit Expense Ratio Pada Bank Bni Syariah. Retrieved from http:/ / repo.iaintulungagung.ac.id/ 11317/

Mariam, N. S., Isnurhadi, I., \& Taufik, T. (2016). IM PACT OF DEBT FIN A N CIN G AN D EQUITY FINANCING ON PROFIT EXPENSE RATIO OF ISLAMIC BANKS IN INDONESIA (Doctoral dissertation, Sriwijaya University).

Muflih, M. (2006). Perilaku Konsumen Dalam Perspektif IImu Ekonomi Islam. Jakarta: PT RajaGrafindo.

Murzinova, K. E. A., Koblanova, A., \& Ansabayeva, D. A. A. (2018). Prosodical means applied in communicative relations. Opción, 34(85-2), 61-96

Pakpahan, P. (2014). Fundamental analysis of Bank Rakyat Indonesia by using residual earnings-PBR (Doctoral dissertation, Thesis, Faculty of Business, Sampoerna University. A vailable at: http:/ / adlermanurungpress. com/ journal/ datajournal).

Quan, L. J., Ramasamy, S., Rasiah, D., Yen, Y. Y., \& Pillay, S. D. (2019). DETERMINANTS OF ISLAMIC BANKING PERFORMANCE: AN EMPIRICAL STUDY IN MALAYSIA (2007TO 2016). H umanities \& Social Sciences R eviews, 7(6), 380-401.

Rusydiana, A., \& AI Parisi, S. (2016). The measurement of Islamic bank performance: A study using maqasid index and profitability. Global Review of Islamic Economics and Business, 4(1), 001-014.

Santoso, T. (2014) Pengaruh Dana Pihak Ketiga dan BI Rate Terhadap Jumlah Penyaluran Pembiayaan pada Bank Pembiayaan Rakyat Syariah di Indonesia Tahun 2010-2012, Skripsi Program Studi Muamalah UIN Raden Fatah Palembang

Siamat, D. (2005). Manajemen Lembaga Keuangan Kebijakan Moneter dan

Susilawati. (2013) Pengaruh Tingkat D ebt Financing dan Equity Financing Terhadap Profit Expense Ratio pada Bank Umum Syariah, Jurnal Program Study Muamalah dan Ekonomi Islam. U niversitas $M$ alukussaleh 
Sukarno, A. S., N urliyani, N., \& Indratiningsih, I. (2014). Powdered Yoghurt Probiotic Quality Produced by Foam-Mat Drying Method with different Drying Temperature and Albumen Level.

Zannati, R., \& Hendryadi, H. (2019). Determinan Non Performing Financing Perbankan Syariah: Perspektif Makro Ekonomi. SERA M BI: Jurnal Ekonomi M anajemen dan Bisnis Islam, 1(3), 91100.

Zarrouk, H., Jedidia, K. B., \& Moualhi, M. (2016). Is Islamic bank profitability driven by same forces as conventional banks?. International Journal of Islamic and $M$ iddle Eastern Finance and M anagement. 9(1), 46-66. https:/ / doi.org/ 10.1108/ IMEFM-12-2014-0120

\section{Profil Penulis}

Deky Anwar adalah dosen Fakultas Ekonomi dan Bisnis Islam UIN Raden Fatah Palembang. Penulis memiliki ketertarikan pada penelitian ekonomi Islam. Email yang dapat dihubungi di: dekyanwar_uin@radenfatah.ac.id.

Riski Ananda Amelia merupakan mahasiswa prodi S1 Perbankan Syariah di Fakultas Ekonomi dan Bisnis Islam UIN Raden Fatah Palembang.

\section{Accepted author version posted online: 20 June 2020}

$$
\text { (c) (i) }
$$

(c)2020 The Author(s). This open access article is distributed under a Creative Commons Attribution (CC-BY) 4.0 license 
SERAMBI: Jurnal Ekonomi Manajemen dan Bisnis Islam Published by LPM P Imperium 